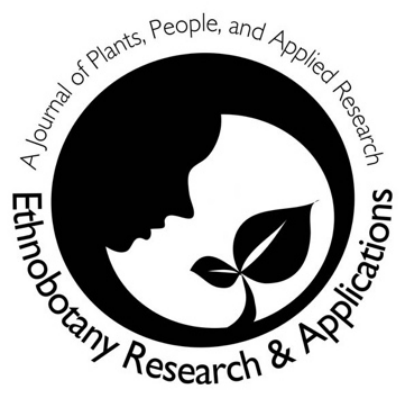

\title{
An ethnobotanical survey of wild food plants used by the local communities of Kumrat Valley in District Upper Dir, Pakistan
}

\author{
Latif Ahmad, Muhammad Riaz, Hammad Ahmad Jan, \\ Andrew J. Semotiuk, Imran Ahmad, Imran Khan, Fayaz Ali, \\ Wajid Rashid and Rainer W. Bussmann
}

\author{
Correspondence \\ Latif Ahmad $^{1 *}$, Muhammad Riaz ${ }^{2}$, Hammad Ahmad Jan ${ }^{3}$, Andrew J. Semotiuk ${ }^{4}$, Imran Ahmad ${ }^{1}$, Imran Khan ${ }^{1}$, \\ Fayaz Ali $^{1}$, Wajid Rashid ${ }^{5}$ and Rainer W. Bussmann ${ }^{6}$ \\ ${ }^{1}$ Department of Botany, Shaheed Benazir Bhutto University, Upper Dir, Pakistan \\ ${ }^{2}$ Department of Pharmacy, Shaheed Benazir Bhutto University Sheringal Dir Upper, Pakistan \\ ${ }^{3}$ Department of Botany, University of Buner, Pakistan \\ ${ }^{4}$ Independent researcher \\ ${ }^{5}$ Department of Environmental and Conservation Sciences University of Swat \\ ${ }^{6}$ Department of Ethnobotany, Institute of Botany, Ilia State University, Tbilisi, Georgia \\ *Corresponding Author: latifahmad1989@sbbu.edu.pk
}

Ethnobotany Research \& Applications 22:20 (2021)

\section{Databases and Inventories}

\begin{abstract}
Background: Local people of the Kumrat Valley, district Upper Dir in Northwest Khyber Pakhtunkhwa, Pakistan rely on wild food plants (WFP) for nutrition, medicine, and monetary value. The present study aimed to accomplish a detailed investigation of local wild food plants and their therapeutic importance to identify innovative organic food products that show potential for local marketing through their use prevalence and monetary value.
\end{abstract}

Methods: Semi-structured interviews and group discussion, were conducted from May to September 2019. In the field survey, 78 local participants were selected using random sampling. Ethnobotanical data were analyzed using Use Value (UV), Informant Agreement Ratio (IAR), and Relative Frequency of Citation (RFC).

Results: A total of 50 species of wild food plants and 2 fungal species of 30 botanical families and 40 genera were encountered. Family Rosaceae dominated with the highest species number ( 6 species), followed by Moraceae and Leguminosae. With respect to life forms, herbs constituted (60\%), trees (30\%), and shrubs (30\%). Ripe fruits (43\%) were the most frequently used part of wild foods.

Conclusions: Important species may serve to guide development initiatives aimed at sustainable and culturally local projects. Traditional knowledge can be used for the synthesis of new allopathic medicines.

Keywords. Ethnobotany; Wild food plant; Medicinal uses; Kumrat Valley; Upper Dir 


\section{Background}

Plant collection and storage is a deeply rooted and shared aspect of human heritage. Around the globe, millions of the people in rural communities depend on gathering of plants for food \& nutrition, medicine, fuel, construction, carpets, animal husbandry, as well as religious ceremonies and rituals (Anderson 2014). The term "wild" refers to those plants that grow without being cultivated (Seal, 2012). From a total of 350000-450,000 known higher plant species, about 5000 have been cultivated or collected for food at certain times, and only 20-30 are regarded as staple foods for humanity (Heywood, 1999). According to Marwat et al. (2009), fruits were likely used first as food. Wild Food Plants (WFP) often contain more nutrients (Ogle and Grivetti, 1985). WFP are thus a significant source of vitamins, minerals, fiber, carbohydrate, and proteins (Marwat et al. 2009), serve as staple food and offer an alternative source of cash income (Teklehaymanot and Giday, 2010). As such WFPs play an important role in ensuring food security and improve the nutrition in the diets of many people especially in developing countries (Abbasi and Guo; FAO 2004; Ghorbani et al. 2012; 2015Lulekal et al. 2011). Moreover, WFPs are potential sources of species for domestication and provide valuable genetic traits for developing new crops through breeding and selection (Ford-Lloyd et al. 2011; Pandey et al. 2008). They can also serve as sources for income in poor communities (Ghorbani et al. 2012; Uprety et al. 2012). Humans have cultivated about 200 species of plant as food crops but only 30 contribute to $95 \%$ of the world's plant food consumption (FAO, 1996; Ghorbani et al. 2012; 2008; Shrestha and Dhillion 2006; Simpson \& Ogorzaly 1995).

Since ancient times, humans have been using plants as medicine and according to some estimates, e.g. approximately $90 \%$ of the tibbi medicines are prepared from herbs. WFPs are often also be used medicinally due to their nutraceutical. In this explorative study, we examined the cultivation, and collection, of local WFPs, their market values, and ethnomedicinal uses among the local communities of Kumrat valley in Upper Dir, Pakistan. The present study had two aims: First, to accomplish a detailed documentation of local WFP uses and to evaluate their potential for local marketing. Second, to identify botanical species and herbal remedies used by the local people for the treatment of human ailments.

\section{Materials and Methods Study area}

The current survey was conducted in Kumrat Valley, located in the North East of Upper Dir, Pakistan, about $120 \mathrm{~km}$ from Dir Khass (Fig. 1) $35^{\circ} 31^{\prime} 59.9^{\prime \prime} \mathrm{N}-35^{\circ} 34^{\prime} 10^{\prime \prime} \mathrm{N}$ and $72^{\circ} 13^{\prime \prime} 38.8 \mathrm{E}-72^{\circ} 11^{\prime} 22^{\prime \prime} \mathrm{E}$. Thall is the nearest town at a distance of aboutv $45 \mathrm{~km}$ from Kumrat valley and is used as the launching point for trips to Kumrat. In Kumrat the elevatiuon ranges from $1371 \mathrm{~m}$ to $1981 \mathrm{~m}$. Climatically the research area falls in a humid subtropical climate zone with four distinct seasons (winter, spring, summer and, autumn). The winter season is harsh and long. Snowfall frequently happens in mid of the winter season (December and January) at high altitudes sites of the research area. The majority of the area is covered with thick vegetation, dominated by wild Pinus spp., and Cedrus spp.

\section{Ethnobotanical investigation}

During the field work, prior informed consent was obtained from all participants, after explaining the aim of the research work. Several trips were conducted from May to September 2019. We interviewed 78 participants using a semi-structured questionnaire, after obtaining oral prior informed consent. The interviews lasted between 15 and 25 minutes, inquiring about local names of the plants, parts used, uses, and economic importance following (Jan et al. 2020).

\section{Plant collection, identification, and preservation}

A total of 50 species of WFP were collected from the study area. Species were identified in the field using Wali et al. (2019). Specimens were collected and verified in the Department of Botany, Shaheed Benazir Bhutto University using the available literature (Jan et al. 2017). Taxonomy and naming of species follow the International Plant Names Index (www.ipni.org) and The Plant List (www.theplantlist.org). The collected vouchers were submitted to the Department of Botany SBBUS.

\section{Classification of wild food plants}

Based on local uses, five basic groups of WFP were identified: I) ripe fruits, II) cooked as vegetable, III) eaten as salad, IV) used as spice, and V) prepared as herbal tea. 


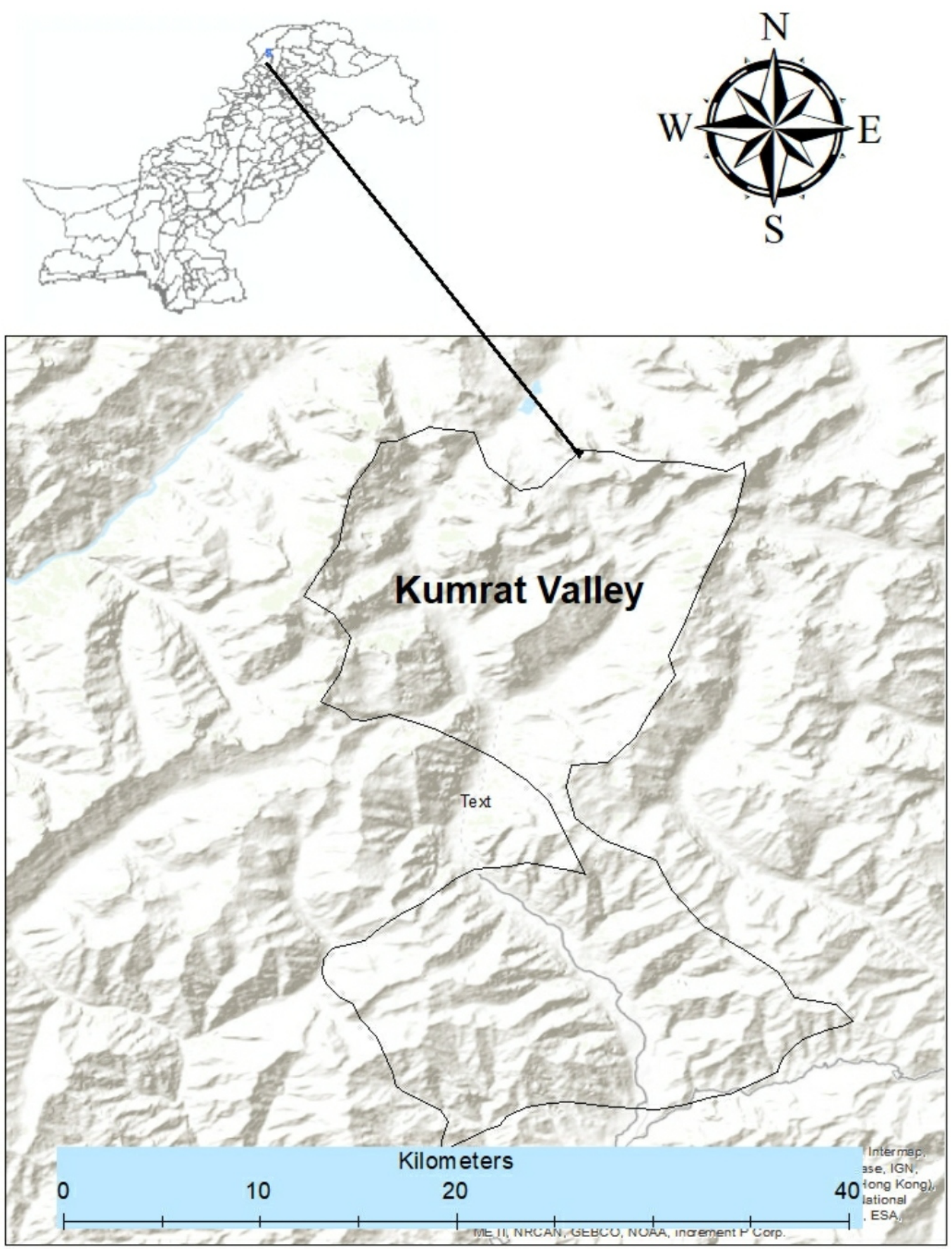

Figure 1. Map of the study area

\section{Quantitative ethnobotany}

\section{Use value}

The use-value assesses the relative significance of each ethnomedicinal plant species based upon its relative used among respondents (Tardio et al. 2008). The use-value (UV) was calculated through the following formula:

$U V=\left(\sum U i\right) / N$ 
where $U i$ is the number of used reports mentioned by each participant and $N$ is the total number of respondents interviewed for a given plants species.

\section{Relative Frequency of Citation (RFC)}

To calculate the indigenous significance of each species, the RFC index was used. It is mainly based on the frequency citation of a species (Muhammad et al. 2019). The RFC was calculated using the formula:

$$
R F C=\frac{F C}{N}
$$

where $F C=$ informants' number for the particular species and, $N=$ total number of participants in the study. The " $\mathrm{N}$ " value of RFC may be zero or 1 . It will be zero in the case when no one respondent cited the significance of a plant and one if all participants report the significance of a plant.

\section{Informant Agreement Ratio (IAR)}

The quantitative index, informant agreement ratio $(I A R)$, was used for the purpose to estimate the variability of the use of ethnobotanical plants. To analyze ethnobotanical data, IAR is widely used. The value of IAR ranges from 0 to 1 . Values close to 1 are considered a high value (close to 1 ) and indicates that relatively few plants are used by a large proportion of the respondents. While a low value (close to 0 ) indicates that the respondents disagree on the taxa's use within a category (Heinrich et al. 1998). Sometimes it is also called the informant consensus factor (Heinrich et al. 2009) and calculated as follows:

$$
I A R=\frac{(N u r-N t)}{(N u r-1)}
$$

where $N u r=$ number of use-reports in each category, $N t=$ number of taxa used in each category

\section{Results and Discussion}

\section{Socio-demographic of participants}

In the present study, a total of 78 local participants were interviewed. Most participants belonged to the age group from $45-65$ years (37 informants), followed by 25-45 year (22) and 65-100 (19). The majority of the interviewed respondents were men (about 90\%), and only 10\% were women, due to cultural restrictions (Fig. 2). Mostly participants in the study area had received little formal education. It was noted that women had more knowledge about wild edible plants used as vegetables and medicines than men, likely because they cook, while male respondents knew more about wild edible fruits.

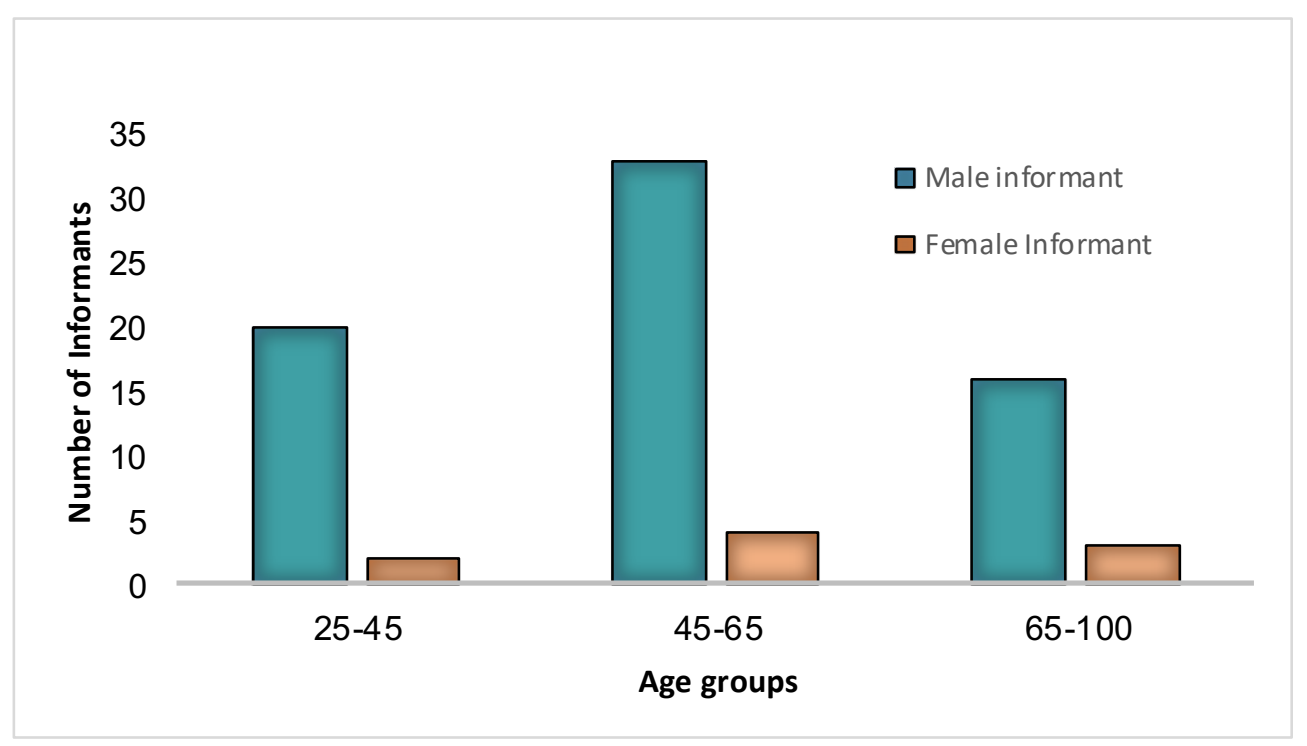

Figure 2. Age distribution of the informants interviewed 


\section{Floristic composition of food plants}

All species and their data are shown in Table 1. A total of 50 species of wild food plant belonging to 30 botanical families and 40 genera were collected. In addition, two fungi, Agaricus campestris and Morchella esculenta were documented. All these recorded species were native to study area. The highest number of WFP belonged to Rosaceae with 6 species followed by Moraceae and Leguminosae (Figure 3). The result of the present study confirmed that people tended to use preferably the plants that are easily available to them in the wild habitat. Comparative literature analysis showed that the highest diversity of WFPs (64 species) was documented from the district Lower Dir (Ahmad et al. 2017), whereas the lowest diversity (47) was reported in Swat district (Khan et al. 2015). The most common growth form of WFPs were herbs with 30 species followed by trees and shrubs (Figure 4).



Figure 3. Number of plant species in different families 
Table 1. Identified wild food plants consumed in Kumrat valley

\begin{tabular}{|c|c|c|c|c|c|c|c|c|}
\hline Scientific name & Local name & $\begin{array}{l}\text { Life } \\
\text { form }\end{array}$ & $\begin{array}{l}\text { Part } \\
\text { used }\end{array}$ & Used categories & Therapeutic uses & $\mathbf{U V}^{\mathbf{b}}$ & FC $^{c}$ & RFC $^{d}$ \\
\hline \multicolumn{9}{|l|}{ Amaryllidaceae } \\
\hline Allium jacquemontii Kunth & Ogakai & Herb & $B L$ & Salad & Hypertension & 0.7 & 23 & 0.29 \\
\hline \multicolumn{9}{|l|}{ Amaranthaceae } \\
\hline Amaranthus viridis $\mathrm{L}$. & Chulai & Herb & LV & Cooked as vegetable & $\begin{array}{l}\text { Abscesses, gonorrhea, } \\
\text { hemorrhoids }\end{array}$ & 0.2 & 15 & 0.19 \\
\hline Chenopodium album L. & Narai Sarmai & Herb & LV & Cooked as vegetable & $\begin{array}{l}\text { Antichloristic and } \\
\text { laxative }\end{array}$ & 0.3 & 19 & 0.24 \\
\hline \multicolumn{9}{|l|}{ Agaricaceae } \\
\hline Agaricus campestris L. & Kharairhy & Herb & WP & Cooked as food & $\begin{array}{l}\text { Body tonic, source of } \\
\text { protein }\end{array}$ & 0.2 & 31 & 0.39 \\
\hline Lycoperdon pratense Pers. & Ghra Anday & Herb & WP & Cooked as food & Source of protein & 0.1 & 21 & 0.26 \\
\hline \multicolumn{9}{|l|}{ Apocynaceae } \\
\hline $\begin{array}{l}\text { Caralluma edulis (Edgew.) Benth. ex } \\
\text { Hook.f. }\end{array}$ & Pamankay & Herb & AP & Cooked as vegetable & Use as antidiabetic & 0.8 & 43 & 0.55 \\
\hline \multicolumn{9}{|l|}{ Apiaceae } \\
\hline Carum carvi L & Zankai & Herb & SE & Spices and Salad & Hypertension & 0.6 & 21 & 0.26 \\
\hline Foeniculum vulgare $\mathrm{L}$ & Kaga & Herb & SE & Spices and Green tea & $\begin{array}{l}\text { Carminative, digestive, } \\
\text { and diuretic }\end{array}$ & 0.4 & 30 & 0.38 \\
\hline \multicolumn{9}{|l|}{ Asteraceae } \\
\hline Lactuca sativa $\mathrm{L}$. & Salad & Herb & LV & $\begin{array}{l}\text { Cooked as vegetable, } \\
\text { salad }\end{array}$ & $\begin{array}{l}\text { Antispasmodic and } \\
\text { digestive }\end{array}$ & 0.07 & 11 & 0.14 \\
\hline \multicolumn{9}{|l|}{ Asparagaceae } \\
\hline Asparagus racemosus Willd. & Tendorlai & Herb & YS & Cooked as vegetable & Hypertension & 0.3 & 33 & 0.42 \\
\hline \multicolumn{9}{|l|}{ Berberidaceae } \\
\hline Berberis lycium Royle & kwarry & Shrub & FR & Used as fruits & Diarrhea & 0.6 & 41 & 0.52 \\
\hline \multicolumn{9}{|l|}{ Brassicaceae } \\
\hline Nasturtium officinale $\mathrm{R} . \mathrm{Br}$. & Talmera & Herb & WP & Cooked as vegetable & Diuretic and purgative & 0.4 & 34 & 0.43 \\
\hline Eruca sativa Mill & Jamama & Herb & AP & Used as salad & Digestive problem & 0.3 & 28 & 0.35 \\
\hline
\end{tabular}




\section{Caryophyllaceae}

Silene conoidea L.

\section{Ebenaceae}

Diospyros lotus L.

Fagaceae

Quercus incana Bartram

\section{Hypericaceae}

Hypericum perforatum $\mathrm{L}$.

\section{Helvellaceae}

Morchella esculenta (L.) Pers.

\section{Lamiaceae}

Mentha spicata $\mathrm{L}$

Mentha longifolia (L.) L.

\section{Leguminosae}

Medicago polymorpha L.

Lathyrus aphaca L.

Vicia faba L.

Lathyrus cicera L.

\section{Lythraceae}

Punica protopunica Balf.f.

Malvaceae

Malva sylvestris $\mathrm{L}$

Malva neglecta Wallr.
Mungotay

Herb AP Cooked as vegetable

Respiratory problems and anti-diabetic

Tree

Used as fruit

Used as febrifuge

Khusay

Herb

\section{WP}

Cooked as food

podina

Inaly

Shpeshtary

Kurkamanai

Herb

AP

Used as tea and salad

Herb

AP

Used as tea and salad

Herb

AP

Herb

Cooked as vegetable

Cooked as vegetable

Used as fruits

MurghayKhpa

Herb

FR

Cooked as vegetable Used as fruits

Chilu

Herb

Cooked as vegetable

Anangori

Tree

FR

Used as fruits

Used as spice

Samchal

Herb LV Cooked as vegetable

Paneerak

Gastrointestinal

Disorders

Stomach problems

Antitumor activities

Hypertension and stomachache Hypertension and

stomachache

$\begin{array}{lll}0.5 & 36 & 0.46 \\ 0.6 & 39 & 0.5\end{array}$

Source of protein

0.09

\section{Source of protein}

0.09

19

0.24

Source of protein 


\section{Moraceae}

Ficus palmata Forssk.

Ficus carica L

Morus alba L.

Morus nigra L.

Morus macroura Miq

\section{Myrtaceae}

Myrtus communis L

\section{Oleaceae}

Olea ferrugineo Wall. ex Aitch

Inzar

Anjeer

speen toot

Tor toot

Shah toot

Manhro

Khona

\section{Oxaildaceae}

Oxalis corniculata L.

Taroky

\section{Papaveraceae}

Papaver rhoeas $\mathrm{L}$.

\section{Polyganaceae}

Rumex dentatus $\mathrm{L}$.

Rumex hastatus D. Don

\section{Pinaceae}

Pinus roxburghii Sarg.

Pinus gerardiana Wall. ex D. Don

Rosaceae

Rubus vestitus Weihe

Rubus. distans D.Don

Soor Gulay

shalkhy

Taroukey

Nakhter

Chalgoza

Karwara

Banganra

$\begin{array}{ccc}\text { Tree } & \text { FR } & \text { Used as fruit } \\ \text { Tree } & \text { FR } & \text { Used as fruit } \\ \text { Tree } & \text { FR } & \text { Used as fruit } \\ \text { Tree } & \text { FR } & \text { Used as fruit } \\ \text { Tree } & \text { FR } & \text { Used as fruit } \\ & & \\ \text { Shrub } & \text { FR } & \text { Used as fruits } \\ & & \\ \text { Tree } & \text { FR } & \text { Used as fruit } \\ & \text { LV } & \text { Green tea }\end{array}$

Herb

Herb

Herb LV Used as salad

Used as fruit
Demulcent, emollient,

and laxative

$0.3 \quad 18$

gastrointestinal and

respiratory problems

Antibacterial activity

Antibacterial and

fungicidal activity

Anti-inflammatory and

diuretic

0.2

0.06

0.07

0.04

Diarrhea, dysentery,

rheumatism

0.8

47

Fever, headaches, and sore throat

$0.5 \quad 28$

Anthelmintic,

depurative, and

diuretic

Treating cough

0.03

Astringent, diuretic, laxative and refrigerant

Increase appetite

Antiseptic, diuretic, and
Diabetes mellitus and 
Ethnobotany Research and Applications

\begin{tabular}{|c|c|c|c|c|c|c|c|c|}
\hline R. ellipticus Sm & Gooraj & Shrub & $\mathrm{FR}$ & Used as fruit & $\begin{array}{l}\text { Coughs, fevers, colic } \\
\text { and sore throat }\end{array}$ & 0.02 & 3 & 0.03 \\
\hline Pyrus pashia Buch-Ham. ex D. Don & Batangi & Tree & FR & Used as fruit & Diarrhea & 0.05 & 4 & 0.051 \\
\hline Fragaria vesca $\mathrm{L}$. & Strawberry & Herb & FR & Used as fruit & $\begin{array}{l}\text { Cardiovascular disease } \\
\text { and stroke }\end{array}$ & 0.1 & 23 & 0.29 \\
\hline Duchesnea indica (Jacks.) Focke & Zmakey toot & Herb & FR & Used as fruit & $\begin{array}{l}\text { Activate the blood } \\
\text { circulation }\end{array}$ & 0.2 & 26 & 0.33 \\
\hline \multicolumn{9}{|l|}{ Rutaceae } \\
\hline Zanthoxylum armatum DC. & Dambara & Tree & FR & Spice and salad & $\begin{array}{l}\text { Asthma, bronchitis, } \\
\text { indigestion }\end{array}$ & 0.6 & 38 & 0.48 \\
\hline \multicolumn{9}{|l|}{ Solanaceae } \\
\hline Solanum nigrum L. & Kermachu & Herb & LV & Cooked as vegetable & Hypertension & 0.6 & 41 & 0.52 \\
\hline \multicolumn{9}{|l|}{ Thymelaeaceae } \\
\hline Daphne mucronata Royle & Lighonay & Shrub & FR & Used as fruit & & 0.03 & 7 & 0.08 \\
\hline \multicolumn{9}{|l|}{ Ulmaceae } \\
\hline Celtis eriocarpa Decne & Taghaga & Tree & $\mathrm{FR}$ & Used as fruit & $\begin{array}{l}\text { Laxative, astringent, } \\
\text { and antioxidant }\end{array}$ & 0.02 & 4 & 0.05 \\
\hline
\end{tabular}

Parts Used ${ }^{a}$ : Seed $=S E$, Leaves $=L V$, Young shoot $=$ YS, Whole plant $=W P$, Fruit $=F R$, Aerial part $=A P, B u l b=B L ; V^{b}=U s e$ Value; FC $=$ Frequency of Citation; RFC ${ }^{d}=$ Relative Frequency of Citation 


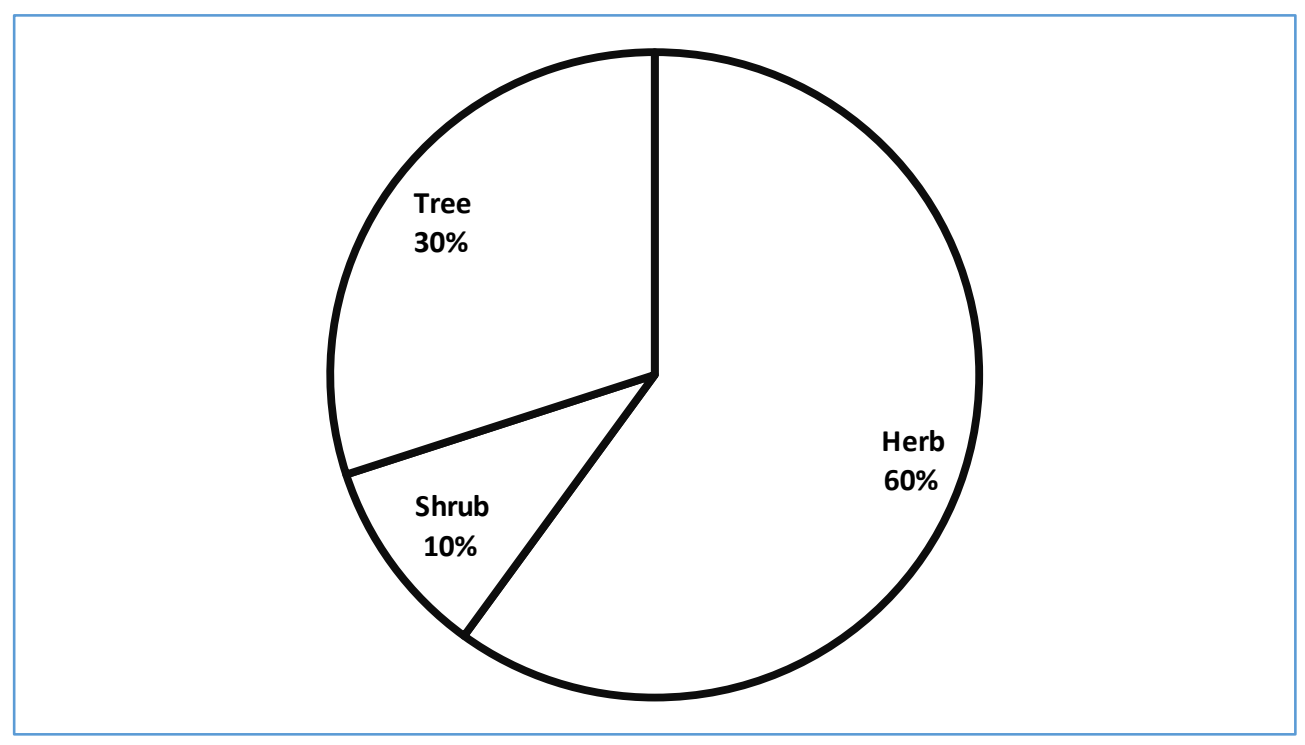

Figure 4. Growth form of medicinal plants in the study area

\section{Part used, Use Reports, and Use Categories}

In our study, the most dominantly used parts were fruits, leaves, and aerial parts (Figure 5). Based on the local uses in the Kumrat valley, raw fruits (25 species) were the most used category of WFPs, followed by cooked as vegetable (20), salad (7), spice (3), and herbal tea (3) (Figure 6). In few cases a single plant part had various uses. In current study we recorded a total of 1215 use-reports from the native residents of the Kumrat Valley (Table 2). To elucidate the importance of the WFPs in the study area, use category values were applied (Inta et al. 2013). The most significant Wild Food category were wild ripe fruits. Several species were used very commolyn e.g., Morus spp., Pyrus pashia, Myrtus communis, Diospyros lotus, Berberis lycium, etc. Wild edible vegetables also played a valuable role in the daily diet of the local population, especially Carallum edulis, Nasturtium officinale, Malva neglecta, Rumex dentatus, and Medicago polymorpha, among othres werre cooked as vegetables in their homes. Similarly local people also used other wild plants as salads, spices, and herbal tea.

Table 2. Number use reports (UR) among food- categories at three survey sites of Kumrat Valley

\begin{tabular}{llll}
\hline $\begin{array}{l}\text { Use } \\
\text { Categories }\end{array}$ & \multicolumn{3}{l}{ Number of use-reports (UR) } \\
\hline & Thull & $\begin{array}{l}\text { Lower } \\
\text { Kumrat }\end{array}$ & $\begin{array}{l}\text { Upper } \\
\text { Kumrat }\end{array}$ \\
\hline Ripe fruits & 197 & 146 & 85 \\
$\begin{array}{l}\text { Cooked } \\
\text { vegetables }\end{array}$ & 45 & 164 & 202 \\
Spices & 15 & 34 & 20 \\
$\begin{array}{l}\text { Green Teas } \\
\text { Salads }\end{array}$ & 105 & 95 & 45 \\
\hline
\end{tabular}

\section{Market value of the wild food plants}

Wild plants often play a very important rule in the livelihoods of poor communities around the globe, and the trade of medicinal plants e.g., will reach $\$ 5$ trillion by 2050 (Jan et al. 2020). Local markets are the places where native people traded there WFPs and so different traditional communities share knowledge regarding WFPs (de Albuquerque et al. 2007). Local people collected species like Morchella esculenta, Berberis lycium, Morus alba, Carum carvi, and Diospyros lotus, and sold them in local market.

\section{Use Value (UV) and Relative Frequency of Citation (RFC)}

In ethnobotany, to check the relative importance of single species, Use Value is employed. The values of UV range from 1 to 0 , and an UV equal or near to 1 indicated high use in a region. If the UV approaches 0 a species is less important. In our study species had UV ranges from 0.9 to 0.02 . The highest UV were recorded for Morchella esculenta, Mentha longifolia, Mentha spicata, Berberis lycium, Carum carvi, Caralluma edulis, Myrtus communis, Zanthoxylum armatum, and Solanum nigrum (Table 1).

Relative Frequency of Citation is used to determine the most commonly occurring spices in an area. Values ranged from 0.78 to 0.07 . The plants with highest RFC were Myrtus communis, Ficus palmata, Malva neglecta, Diospyros lotus, Mentha spicata, Zanthoxylum armatum, Duchesnea indica, Solanum nigrum, and Olea ferruginea (Table 1). 




Figure 5. Percentage of plant part used of the WFP

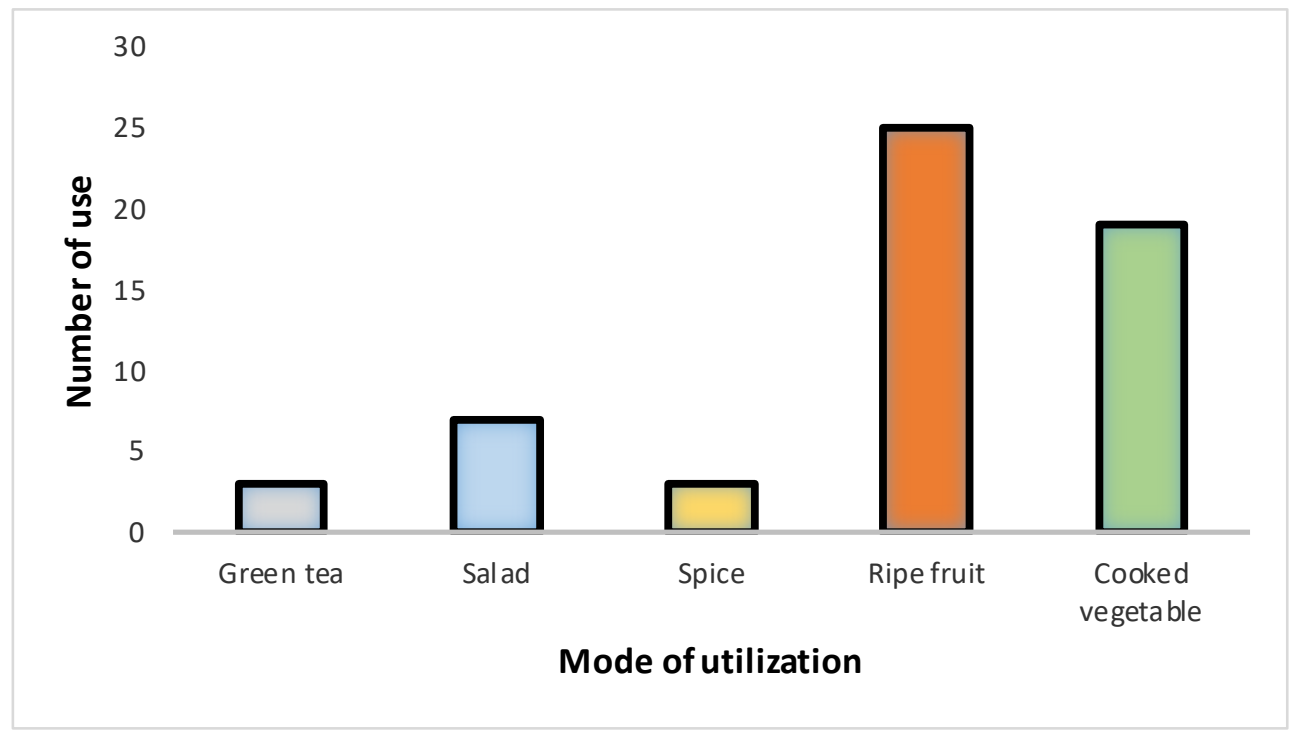

Figure 6. Mode of utilization for each food category

\section{Informant Agreement Ratio}

The informant agreement ratio $(I A R)$ provides information about the uniformity or agreement of the interviewed respondents in certain Use-categories, e.g., cooked vegetable or spice. In this study, we compared the number of use reports, and IARs in the three different sites of Kumrat Valley (Table $2 \& 3$ ). The results show that wild edible fruits obtained a high IAR with 0.81. The local people mostly used the wild fruits of Pinus gerardiana, Myrtus communis, Ficus spp., Morus spp., Punica protopunica, and Diospyros lotus.

Table 3. Informant agreement ratio (IAR) for each food-category

\begin{tabular}{cccc}
\hline Use Categories & \multicolumn{3}{c}{ Informant agreement ratio (IAR) } \\
\hline & Thull & $\begin{array}{c}\text { Lower } \\
\text { Kumrat }\end{array}$ & $\begin{array}{c}\text { Upper } \\
\text { Kumrat }\end{array}$ \\
\hline $\begin{array}{c}\text { Ripe fruits } \\
\text { Cooked }\end{array}$ & 0.75 & 0.8 & 0.9 \\
vegetables & 0.6 & 0.7 & 0.5 \\
Spices & 0.5 & 0.4 & 0.2 \\
Herbal Teas & 0.4 & 0.5 & 0.3 \\
Salads & 0.3 & 0.2 & 0.15 \\
\hline
\end{tabular}

\section{Conclusions}

During present research work, we recorded the useful traditional knowledge related to WFPs form the local communities of Kumrat Valley Dir Upper, Pakistan. We identified 50 WFP species commonly used by local people both for their own needs and to as sell them in local 
markets. To best of our knowledge, this is the first report from Kumrat valley, and should provide a solid basis for more detailed future research.

\section{Declarations}

List of abbreviations: N/A

Ethics approval and consent to participate: This ethnomedicinal study was approved by the ethical committees of the Department of Botany, of the University and Herbarium, Department of Botany Islamia College Peshawar, Pakistan and Biodiversity Action Plan (BAP-2010-2020) for Pakistan. Before conducting interviews, the individual prior informed consent was obtained from all participants. No further ethics approval was required. All work conducted was carried out under the stipulations of the Nagoya Protocol on Access to Genetic Resources and the Fair and Equitable Sharing of Benefits Arising from their Utilization to the Convention on Biological Diversity. The right to use and authorship of any traditional knowledge of all participants is maintained, and any use of this information, other than for scientific publication, does require additional prior consent of the traditional owners, as well as a consensus on access to benefits resulting from subsequent use.

Consent for publication: Not applicable - no personal data are included in this manuscript.

Availability of data and materials: Please indicate if any datasets have been deposited in public repositories.

Competing interests: The authors declare that they have no competing interest and it is certified that we have no commercial associations (e.g, consultancies, stock ownership, equity interest, patent/licensing arrangements, etc.) that might pose a conflict of interest in connection with the submitted article.

Funding: This study did not receive funding.

Authors' contributions: LA and AKJ designed the study; AKJ, LA and HAJ conducted the fieldwork, LA, HAJ, MR and WR conducted the main statistical analysis and wrote the manuscript, RWB, AJS and HAJ revised the data analysis and the manuscript; all authors read, corrected and approved the manuscript.

\section{Acknowledgments}

The authors thank the local people of the study area for providing relevant information about wild food plant usage. This research was financed by the Higher Education Commission, Government of Pakistan HEC Award Letter No. 21- 2512/SRGP/R\&D/HEC/2019.

\section{Literature cited}

Abbasi AM, Xinbo Guo X. 2015. Proximate composition, phenolic contents and in vitro antioxidant properties of Pimpinella stewartii (A wild medicinal food). Journal of Food and Nutrition Research 3:330-336.

Anderson PC (ed.) 2014. Early agricultural remnants and technical heritage (EARTH): 8,000 years of resilience and innovation. Oxbow Books;

Arenas P, Scarpa G.F. 2007. Edible wild plants of the chorote Indians, Gran Chaco, Argentina. Botanical Journal of the Linnean Society 153:73-85.

de Albuquerque Júnior, Durval M, Albuquerque Júnior Albuquerque Jr. 2007. História: a arte de inventar o passado: ensaios de teoria da história. EDUSC.

FAO. 2004. The State of Food Insecurity in the World: Monitoring the Progress towards the World Food Summit and Millennium Development Goals. Rome, Italy: Food and Agriculture Organization of the United Nations (FAO). Available at: http://www.fao.org/3/a-y5650e.pdf. Accessed 15 May 2016

FAO. Report on the State of the World's Plant Genetic resources. Leipzig Germany: International Technical Conference on Plant Genetic Resources; 1996. p. 17-23. FAO ITCPGR/96/3.

Ghorbani A, Langenberger G, Sauerborn J. 2012. A comparison of the wild food plant use knowledge of ethnic minorities in Naban River Watershed National Nature Reserve, Yunnan, SW China. Journal of Ethnobiology and Ethnomedicine 8:17.

Heinrich M, Edwards S, Moerman DE, Leonti M. 2009. Ethnopharmacological field studies: A critical assessment of their conceptual basis and methods. Journal of Ethnopharmacology 124:1-7.

Heinrich M, Inta A, Frei B, Weimann C, Sticher O. 1998. Medicinal Plants in Mexico: Healers' Consensus and Cultural Importance. Social Science and Medicine 47:1859-1871.

Inta A, Trisonthi P, Trisonthi C. 2013. Analysis of Traditional Knowledge in Medicinal Plants Used by Yuan in Thailand. Journal of Ethnopharmacology 149:344-51. 
Jan HA, Jan S, Bussmann RW, Ahmad L, Wali S, Ahmad N. 2020. Ethnomedicinal survey of the plants used for gynecological disorders by the indigenous community of District Buner, Pakistan. Ethnobotany Research and Applications 19:1-18.

Jan HA, Jan S, Bussmann RW, Wali S, Sisto F, Ahmad L. 2020. Complementary and alternative medicine research, prospects and limitations in Pakistan: A literature review. Acta Ecologica Sinica 40:451-463.

Jan HA, Wali S, Ahmad L, Jan S, Ahmad N, Ullah N. 2017. Ethnomedicinal survey of medicinal plants of Chinglai valley, Buner district, Pakistan. European Journal of Integrative Medicine 13:64-74.

Joshi N, Kehlenbeck K, Maass BL. 2007. Traditional, neglected vegetables of Nepal: Their sustainable utilization for meeting human needs. In Conference on International Agricultural Research for Development, Tropentag (pp. 110).

Khan MPZ, Ahmad M, Zafar M, Sultana S, Ali MI, Sun H. 2015. Ethnomedicinal uses of edible wild fruits (EWFs) in Swat Valley, Northern Pakistan. Journal of Ethnopharmacology 173:191-203.

Marwat SK, Khan MA, Khan MA, Ahmad M, Zafar M, Rehman F, Sultana S. 2009. Fruit plant species mentioned in the Holy Qura'n and Ahadith and their ethnomedicinal importance. American-Eurasian Journal of Agricultural and Environmental Science 5:284-295.

Misra S, Maikhuri RK, Kala CP, Rao KS, Saxena KG. 2008. Wild leafy vegetables: A study of their subsistence dietetic support to the inhabitants of Nanda Devi Biosphere Reserve, India. Journal of Ethnobiology and Ethnomedicine 4:15.

Ogle BM, Grivetti LE. 1985. Legacy of the chameleon: Edible wild plants in the kingdom of Swaziland, Southern Africa. A cultural, ecological, nutritional study. Part IV-nutritional analysis and conclusions. Ecology of Food and Nutrition 17:41-64

Seal T. 2012. Evaluation of nutritional potential of wild edible plants, traditionally used by the tribal people of Meghalaya state in India. American Journal of Plant Nutrition and Fertilization Tech 2:19-26.

Sher $\mathrm{H}$, Hussain F. 2009. Ethnobotanical evaluation of some plant resources in Northern part of Pakistan. African journal of Biotechnology 8:4066-4076.

Shrestha PM, Dhillion SS. 2006. Diversity and traditional knowledge concerning wild food species in a locally managed forest in Nepal. Agroforestry Systems 66:55-63.

Simpson BB, Ogorzaly MC. 1995. Spices, herbs, and perfumes. Economic Botany: Plants in Our World, McGraw-Hill, New York, 278-301.

Tardio J, Pardo-de-Santayana M. 2008. Cultural importance indice: a comparative analysis based on the useful wild plants of Southern Cantabria (Northern Spain). Economic Botany 62:24-39.

Uprety Y, Poudel RC, Shrestha KK, Rajbhandary S, Tiwari NN, Shrestha UB, Asselin H. 2012. Diversity of use and local knowledge of wild edible plant resources in Nepal. Journal of Ethnobiology and Ethnomedicine 816.

Vitalini S, Puricelli C, Ciuchi D, Segale A, Fico G. 2013. Traditional knowledge on medicinal and food plants used in Val San Giacomo (Sondrio, Italy): an alpine ethnobotanical study. Journal of Ethnopharmacology 145:517-529.

Wali S, Jan HA, Bussmann RW. 2019. Quantitative ethnomedicinal study of indigenous medicinal plants used for digestive disorders of Laspur Valley, Chitral, Northern Pakistan. Ethnobotany Research and Applications 18:1-18.

Teklehaymanot T, Giday M. 2010. Ethnobotanical study of wild edible plants of Kara and Kwego semi-pastoralist people in Lower Omo River Valley, Debub Omo Zone, SNNPR Ethiopia. Journal of Ethnobiology and Ethnomedicine 6:23.

Lulekal E, Asfaw Z, Kelbessa E, Van Damme P. 2011. Wild edible plants in Ethiopia: a review on their potential to combat food insecurity. Africa Focus 24:71-121.

Ghorbani A, Langenberger G, Sauerborn J: A comparison of the wild food plant use knowledge of ethnic minorities in Naban River Watershed National Nature Reserve, Yunnan, SW China. Ethnobiology and Ethnomedicine 2012:8:17.

Ford-Lloyd BV, Schmidt M, Armstrong SJ, et al. 2011. Crop wild relatives undervalued, underutilized and under threat? BioScience 61:559-565.

Pandey A, Tomer AK, Bhandari DC, Pareek SK. 2008. Towards collection of wild relatives of crop plants in India. Genetic Resources and Crop Evolution 55:187-202. 